Красинский Владислав Вячеславович, кандидат юридических наук, член Общественного консультативного научно-методического Совета при ЦИК России

\title{
ПРАВОВЫЕ ПОЗИЦИИ КОНСТИТУЦИОННОГО СУДА РОССИЙСКОЙ ФЕДЕРАЦИИ ПО ВОПРОСАМ ОГРАНИЧЕНИЯ ПРАВ РОССИЙСКИХ ГРАЖДАН НА УЧАСТИЕ В ВЫБОРАХ В СВЯЗИ С НАЛИЧИЕМ ИНОСТРАННОГО ГРАЖДАНСТВА ЛИБО ВИДА НА ЖИТЕЛЬСТВО НА ТЕРРИТОРИИ ИНОСТРАННОГО ГОСУДАРСТВА
}

Красинский В.В. Правовые позиции Конституционного Суда Российской Федерации по вопросам ограничения прав российских граждан на участие в выборах в связи с наличием иностранного гражданства либо вида на жительство на территории иностранного государства // Современное право. 2011. № 6. С. 46-52; www.krasinskiy.ru

В статье анализируются правовые позиции Конституционного Суда Российской Федерации по вопросам ограничения прав граждан на участие в выборах. Автором рассмотрены подходы органов конституционной юстиции к решению вопросов гражданства и правовые требования к организаторам выборов.

Ключевые слова: выборы, избирательный процесс, ограничения прав граждан, Конституционный Суд Российской Федерации, Европейский Суд по правам человека.

The article examines legal positions of the Constitutional Court of the Russian Federation concerning restriction of the electoral rights of citizens. The author studies the positions of bodies of the constitutional justice to the decision of questions of citizenship and legal requirements to organizers of elections.

Key words: elections, electoral process, restrictions of the rights of citizens, Constitutional Court of the Russian Federation, European Court of Human Rights.

В соответствии с пунктом 3.1 статьи 4 Федерального закона от 12 июня 2002 г. № 67-Ф3 «Об основных гарантиях избирательных прав и права на участие в референдуме граждан Российской Федерации» не имеют права быть избранными граждане Российской Федерации, имеющие гражданство иностранного государства либо вид на жительство или иной документ, 
подтверждающий право на постоянное проживание гражданина Российской Федерации на территории иностранного государства.

Аналогичные ограничения для кандидатов, связанные с наличием гражданства иностранного государства либо вида на жительство или иного документа, подтверждающего право на постоянное проживание гражданина Российской Федерации на территории иностранного государства, закреплены в пункте 5.1 статьи 3 Федерального закона от 10 января 2003 г. № 19-Ф3 «О выборах Президента Российской Федерации» и статье 5 Федерального закона от 18 мая 2005 г. № 51-Ф3 «О выборах депутатов Государственной Думы Федерального Собрания Российской Федерации».

Данное требование к кандидатам, баллотирующимся на выборах в органы государственной власти, было введено законодателем с учетом интересов национальной безопасности в целях ограничения иностранного влияния на политические процессы, проходящие в Российской Федерации, а также укрепления политико-правовой связи избираемых народных представителей с российским государством ${ }^{1}$.

Конституционность и обоснованность приведенных законодательных положений была подтверждена решениями Конституционного и Верховного Судов Российской Федерации.

В Определении от 4 декабря 2007 г. № 797-О-О «Об отказе в принятии к рассмотрению жалобы гражданина Кара-Мурзы Владимира Владимировича на нарушение его конституционных прав положением пункта 3.1 статьи 4 Федерального закона «Об основных гарантиях избирательных прав и права на участие в референдуме граждан Российской Федерации» Конституционный Суд Российской Федерации обосновал правомерность ограничения пассивного избирательного права в связи с наличием гражданства иностранного государства.

1 Подробней о правовом регулировании отношений гражданства в интересах обеспечения национальной безопасности России см. Красинский В.B. Конституционно-правовое регулирование российского гражданства в интересах обеспечения национальной безопасности // Политика и общество. 2006. № 1. C. 63-72. 
По мнению Конституционного Суда Российской Федерации, «поскольку гражданин Российской Федерации, имеющий гражданство иностранного государства, находится в политико-правовой связи одновременно с Российской Федерацией и с соответствующим иностранным государством, перед которым он также несет конституционные и иные, вытекающие из законов данного иностранного государства, обязанности, значение для него гражданства Российской Федерации как политикоюридического выражения ценности связи с Отечеством объективно снижается. Волеизъявление такого лица - в случае избрания его депутатом законодательного (представительного) органа государственной власти - в процессе реализации депутатских полномочий может обусловливаться не только требованиями конституционного правопорядка Российской Федерации и интересами ее народа, но и требованиями, вытекающими из принадлежности к иностранному государству.

Между тем формально-юридическая либо фактическая подчиненность депутата законодательного (представительного) органа суверенной воле не только народа Российской Федерации, но и народа иностранного государства не согласуется с конституционными принципами независимости депутатского мандата и государственного суверенитета и ставит под сомнение верховенство Конституции Российской Федерации» ${ }^{1}$.

Аналогичное дело было разрешено Верховным Судом Российской Федерации по заявлению В.К. Буковского об отмене постановления Центральной избирательной комиссии Российской Федерации от 22 декабря 2007 г. № 80/644-5 «Об отказе в регистрации группы избирателей, созданной

${ }^{1}$ Определение Конституционного Суда Российской Федерации от 4 декабря 2007 г. № 797-О-О «Об отказе в принятии к рассмотрению жалобы гражданина Кара-Мурзы Владимира Владимировича на нарушение его конституционных прав положением пункта 3.1 статьи 4 Федерального закона «Об основных гарантиях избирательных прав и права на участие в референдуме граждан Российской Федерации» // Рос. газ. 2007. 26 декабря. 
для поддержки самовыдвижения Буковского В.К. кандидатом на должность Президента Российской Федерации, и ее уполномоченных представителей»1 .

В период проведения выборов депутатов Государственной Думы Федерального Собрания Российской Федерации пятого созыва по заявлению ЦИК России Верховным Судом Российской Федерации была отменена регистрация ряда кандидатов в депутаты Государственной Думы Федерального Собрания Российской Федерации, включенных в зарегистрированные федеральные списки кандидатов, в связи с отсутствием у них гражданства Российской Федерации либо наличием гражданства иностранного государства ${ }^{2}$.

Ограничение избирательных прав в отношении лиц, имеющих иностранное гражданство, применяется в законодательстве большинства государств.

Гражданство представляет собой не только политическую принадлежность к конкретному государству, но и состояние подвластности, подчинения лица суверенной государственной власти. С одной стороны, гражданство выступает как средство и способ защиты прав индивида, с другой, как институт защиты прав и интересов государства ${ }^{3}$.

Наличие иностранного гражданства предполагает ограничение прав и возможностей участия лица в управлении делами государства. В связи с этим иностранные граждане не могут избирать и быть избранными в выборные государственные органы, занимать государственные должности, участвовать

1 Решение Верховного Суда Российской Федерации от 28 декабря 2007 года по заявлению В.К. Буковского об отмене постановления Центральной избирательной комиссии Российской Федерации от 22 декабря 2007 г. № 80/644-5 «Об отказе в регистрации группы избирателей, созданной для поддержки самовыдвижения Буковского В.К. кандидатом на должность Президента Российской Федерации, и ее уполномоченных представителей».

${ }^{2}$ Решение Верховного Суда Российской Федерации от 9 ноября 2007 г. № ГКПИ07-1426 по заявлению Центральной избирательной комиссии Российской Федерации об отмене регистрации кандидата в депутаты Государственной Думы Федерального Собрания Российской Федерации пятого созыва Наджаряна С.Н., включенного в зарегистрированный федеральный список кандидатов, выдвинутый политической партией «Либерально-демократическая партия России»; Решение Верховного Суда Российской Федерации от 24 ноября 2007 г. № ГКПИ07-1534 по заявлению Центральной избирательной комиссии Российской Федерации об отмене регистрации кандидата в депутаты Государственной Думы Федерального Собрания Российской Федерации пятого созыва Нисанова Г.С., включенного в зарегистрированный федеральный список кандидатов, выдвинутый политической партией «Либерально-демократическая партия России».

\footnotetext{
${ }^{3}$ Кутафин О.Е. Российское гражданство. М.: Юрист, 2003. С. 7, 79.
} 
во всенародных референдумах, быть учредителями и членами политических партий.

Статья 12 Федерального закона от 25 июля 2002 г. № 115-Ф3 «О правовом положении иностранных граждан в Российской Федерации» устанавливает, что «иностранные граждане в Российской Федерации не имеют права избирать и быть избранными в федеральные органы государственной власти, органы государственной власти субъектов Российской Федерации, а также участвовать в референдуме Российской Федерации и референдумах субъектов Российской Федерации» ${ }^{1}$.

В соответствии с Федеральным законом «Об основных гарантиях избирательных прав и права на участие в референдуме граждан Российской Федерации» иностранные граждане, лица без гражданства, иностранные организации не вправе осуществлять деятельность, способствующую либо препятствующую выдвижению кандидатов, списков кандидатов, избранию зарегистрированных кандидатов, выдвижению инициативы проведения референдума и проведению референдума, достижению определенного результата на выборах, референдуме 2 .

Буквальное толкование пункта 3.1 статьи 4 Федерального закона от 12 июня 2002 г. № 67-Ф3 «Об основных гарантиях избирательных прав и права на участие в референдуме граждан Российской Федерации» позволяет сделать вывод о наличии двух самостоятельных оснований ограничения пассивного избирательного права российских граждан:

- наличие гражданства иностранного государства;

- наличие вида на жительство или иного документа, подтверждающего право на постоянное проживание гражданина Российской Федерации на территории иностранного государства.

Согласно ст. 3 Федерального закона от 31 мая 2002 г. № 62-Ф3 «О гражданстве Российской Федерации» вид на жительство рассматривается

\footnotetext{
${ }^{1}$ Рос. газ. 2002. 31 июля.

2 Рос. газ. 2002. 15 июня.
} 
законодателем как документ, удостоверяющий личность лица без гражданства, выданный в подтверждение разрешения на постоянное проживание на территории Российской Федерации лицу без гражданства или иностранному гражданину и подтверждающий их право на свободный выезд из Российской Федерации и возвращение в Российскую Федерацию1.

Вид на жительство является документом, необходимым для регистрации иностранного гражданина и лица без гражданства по месту жительства 2 .

Статус иностранного гражданина, постоянно проживающего на территории государства (имеющего вид на жительство), качественно отличается от правового статуса иностранного гражданина, временно пребывающего в государстве ${ }^{3}$.

Иностранным гражданам, постоянно проживающим в государстве (имеющим вид на жительство), гарантируются личные, социально-трудовые, имущественные, культурные права. Они могут вступать в общественные объединения, если это не противоречит их уставам. На основании международных договоров Российской Федерации и в порядке, установленном законом, иностранные граждане, постоянно проживающие на территории соответствующего муниципального образования, имеют право избирать и быть избранными в органы местного самоуправления, участвовать в иных избирательных действиях на указанных выборах, а также участвовать в местном референдуме на тех же условиях, что и граждане Российской Федерации.

Таким образом, наличие вида на жительство или иного документа, подтверждающего право на постоянное проживание гражданина на

\footnotetext{
${ }^{1}$ Рос. газ. 2002.5 июня.

${ }^{2}$ Статья 17 Федерального закона от 18 июля 2006 г. № 109-Ф3 «О миграционном учете иностранных граждан и лиц без гражданства в Российской Федерации» // Рос. газ. 2006. 20 июля.

${ }^{3}$ В соответствии со статьей 2 Федерального закона «О правовом положении иностранных граждан в Российской Федерации» лицо, получившее вид на жительство, признается постоянно проживающим в Российской Федерации иностранным гражданином. Согласно распространенной в международном сообществе иммиграционной практике получение вида на жительство может служить необходимым этапом приема в гражданство соответствующего государства, хотя и не означает обязательного его приобретения в дальнейшем.
} 
территории иностранного государства, обладает двойственной правовой природой. С одной стороны, оно позволяет иностранным гражданам, постоянно проживающим на территории соответствующего муниципального образования, реализовать свои избирательные права на муниципальных выборах и референдумах, проходящих в Российской Федерации. С другой стороны, оно ограничивает пассивное избирательное право граждан Российской Федерации, располагающих подобными документами.

Рассмотрим реализацию комментируемых законодательных положений в практике судопроизводства. При проведении дополнительных выборов депутатов Законодательного Собрания Тверской области четвертого созыва 11 октября 2009 г. кандидату Ч. было отказано в регистрации на основании отсутствия у него пассивного избирательного права в связи с наличием иного документа, подтверждающего право на постоянное проживание на территории иностранного государства ${ }^{1}$. При подаче документов для регистрации в качестве кандидата Ч. представил документ «удостоверение лица индийского происхождения». Организаторами выборов и Судебной коллегией по гражданским делам Тверского областного суда были направлены запросы в уполномоченный орган, обладающий информацией о наличии (отсутствии) у граждан Российской Федерации вида на жительство или иного документа, подтверждающего право на постоянное проживание гражданина России на территории иностранного государства - МИД России. Из переписки с МИД России было установлено, что удостоверение лица индийского происхождения дает его владельцу право на безвизовый въезд в Индию и постоянное проживание на территории этой страны в течение 15 лет с последующим продлением еще на 15 лет $^{2}$. На этом основании суд сделал вывод, что у кандидата Ч. отсутствовало пассивное избирательное право на соответствующих выборах в связи с наличием у него удостоверения

\footnotetext{
${ }^{1}$ Райков Г.И, Песенко В.Н. История двух судебных дел // Журнал о выборах. 2009. № 6. С. 21-29.

2 Там же. С. 21.
} 
лица индийского происхождения, являющегося иным документом, подтверждающим право Ч. на постоянное проживание гражданина Российской Федерации на территории иностранного государства. Впоследствии Ч. обжаловал это решение Судебной коллегии по гражданским делам Тверского областного суда от 9 сентября 2009 г. в кассационном порядке в Верховный Суд Российской Федерации, который не нашел оснований для его отмены (Определение Верховного Суда Российской Федерации от 17 сентября 2009 г. по делу № 35-ГО9-11).

Нормативным правовым актом, регламентирующим предоставление избирательным комиссиям информации о наличии (отсутствии) у граждан Российской Федерации гражданства иностранного государства либо вида на жительство или иного документа, подтверждающего право на постоянное проживание гражданина России на территории иностранного государства, является Постановление Правительства Российской Федерации от 17 сентября 2007 г. № 589 «О мерах по оказанию содействия избирательным комиссиям в реализации полномочий при подготовке и проведении выборов депутатов Государственной Думы Федерального Собрания Российской Федерации и Президента Российской Федерации»².

Следует отметить, что подобного рода сведения предоставляются МИД России лишь по запросам Центральной избирательной комиссии Российской Федерации применительно к федеральным избирательным кампаниям. Порядок, сроки и формы взаимодействия избирательных комиссий других уровней (избирательных комиссий субъектов Российской Федерации, комиссий муниципальных образований, окружных и территориальных комиссий) с МИД России при проведении региональных и муниципальных выборов нормативно не урегулированы.

В настоящее время европейскими международными организациями (в первую очередь, Советом Европы) предпринимаются активные усилия по

\footnotetext{
1 Там же. С. 22.

2 Пункт 9 Постановления Правительства Российской Федерации от 17 сентября 2007 г. № 589 // Рос. газ. 2007. 26 сентября.
} 
предоставлению иностранным гражданам и лицам с множественным гражданством полного объема политических прав, адекватного правосубъектности граждан государств.

Важное значение для развития правовых принципов, касающихся множественного гражданства, имело Постановление Европейского Суда по правам человека от 18 ноября 2008 г. по делу «Танасэ и Киртоакэ против Молдовы», а также Постановление Большой Палаты Европейского Суда по правам человека от 27 апреля 2010 г. по делу «Танасэ против Молдовы»1

Предметом рассмотрения являлось законодательство Республики Молдова, устанавливающее ограничения на замещение депутатских мандатов лицами, имеющими множественное гражданство. 29 апреля 2008 г. в Молдове был принят Закон № 273, в соответствии с которым лицо с двойным гражданством в момент регистрации кандидатом в депутаты Парламента должно было информировать Центральную избирательную комиссию о гражданстве иностранного государства. В случае избрания на выборах указанное лицо обязывалось представить в Конституционный Суд официальное подтверждение инициирования процедуры отказа от двойного гражданства. В противном случае депутатский мандат подлежал аннулированию.

Заявителем выступил заместитель председателя Либеральнодемократической партии Молдовы Александр Тэнасе, имеющий гражданство Румынии и избранный в Парламент Молдовы в 2009 г. После выборов заявитель возбудил процедуру отказа от румынского гражданства в целях подтверждения своего мандата Конституционным судом.

В Постановлении от 18 ноября 2008 г. Европейский Суд по правам человека установил, что по делу было допущено нарушение требований

1 Постановление Европейского Суда по правам человека от 18 ноября 2008 г. по делу «Танасэ и Киртоакэ против Молдовы» (Tanase and Chirtoaca v. Moldova) // Бюллетень Европейского Суда по правам человека. 2009. № 3. С. 44-47; Case of Tanase v. Moldova (Application no. 7/08). European Court of Human Rights. Grand Chamber. Strasbourg. 27 April 2010. 
статьи 3 Протокола № 1 Европейской Конвенции, гарантирующей право на свободные выборы.

Большая Палата Европейского Суда по правам человека 27 апреля 2010 г. постановила, что запрет на двойное гражданство для депутатов парламента нарушает статью 3 Протокола № 1 Европейской Конвенции. Положения, препятствующие избранным депутатам, имеющим множественное гражданство, занимать места в парламенте, были признаны несоразмерными.

Под влиянием европейского опыта Конституционный Суд Российской Федерации принял Постановление по жалобе А.М. Малицкого, в котором фактически были поставлены под сомнения прежние правовые позиции Конституционного Суда Российской Федерации по вопросам ограничения прав российских граждан на участие в выборах в связи с наличием иностранного гражданства либо вида на жительство на территории иностранного государства.

Несмотря на то, что в деле «Тэнасе и Киртоакэ против Молдовы» речь шла об ограничении пассивного избирательного права депутатов парламента, имеющих множественное гражданство, а в деле А.М. Малицкого рассматривалась конституционность правовых требований об отсутствии у членов территориальных избирательных комиссий вида на жительство, подтверждающего право на постоянное проживание на территории иностранного государства, Конституционный Суд Российской Федерации в решении по делу Малицкого поменял свою прежнюю позицию по проблеме фактической (или формально-юридической) подчиненности лица суверенной воле иностранного государства.

Право граждан на участие в выборах реализуется не только избирателями, кандидатами в депутаты (на выборные должности), наблюдателями, но и организаторами выборов. Элементом характеристики специального правового статуса организатора выборов являются требования к членам избирательных комиссий, соответствие которым предоставляет лицу право занимать эту должность. 
Законодательные требования к работе в составе избирательных комиссий предполагают отсутствие у членов комиссий гражданства иностранного государства либо вида на жительство или иного документа, подтверждающего право на постоянное проживание гражданина Российской Федерации на территории иностранного государства.

Проанализируем правовые позиции Конституционного Суда Российской Федерации, сформулированные по делу о проверке конституционности подпункта «а» пункта 1 и подпункта «а» пункта 8 статьи 29 Федерального закона «Об основных гарантиях избирательных прав и права на участие в референдуме граждан Российской Федерации» в связи с жалобой гражданина А.М. Малицкого ${ }^{1}$.

7 декабря 2006 г. гражданин А.М. Малицкий был назначен членом территориальной избирательной комиссии района «Преображенское» г. Москвы с правом решающего голоса. 26 июня 2009 г. в Московскую городскую избирательную комиссию поступило уведомление А.M. Малицкого о том, что с 12 июня 2009 г. ему предоставлен вид на жительство на территории Литовской Республики. Московская городская избирательная комиссия решением от 9 июля 2009 г. в соответствии с подпунктом «а» пункта 8 статьи 29 Федерального закона «Об основных гарантиях избирательных прав и права на участие в референдуме граждан Российской Федерации» прекратила полномочия члена территориальной комиссии А.М. Малицкого и назначила в состав территориальной комиссии другого представителя. Решением Московского городского суда от 10 августа 2009 г., оставленным без изменения Определением Верховного Суда Российской Федерации от 24 августа 2009 г., в отмене решения Московской городской избирательной комиссии Малицкому было отказано.

В соответствии с подпунктом «а» пункта 1 статьи 29 Федерального закона «Об основных гарантиях избирательных прав и права на участие в референдуме граждан Российской Федерации» членами избирательной

\footnotetext{
${ }^{1}$ Рос. газ. 2010. 7 июля.
} 
комиссии с правом решающего голоса не могут быть граждане Российской Федерации, имеющие гражданство иностранного государства либо вид на жительство или иной документ, подтверждающий право на постоянное проживание гражданина Российской Федерации на территории иностранного государства.

Полномочия члена избирательной комиссии с правом решающего голоса прекращаются немедленно в случае получения членом комиссии вида на жительство или иного документа, подтверждающего право на постоянное проживание гражданина Российской Федерации на территории иностранного государства ${ }^{1}$. Таким образом, «наличие у гражданина Российской Федерации вида на жительство является препятствием к осуществлению им полномочий члена избирательной комиссии с правом решающего голоса, в связи с тем, что осуществление таким лицом полномочий может обусловливаться не только требованиями конституционного правопорядка Российской Федерации и интересами ее народа, но и требованиями, вытекающими из его принадлежности к иностранному государству»².

Формально юридическая либо фактическая подчиненность организатора выборов в Российской Федерации, имеющего вид на жительство в иностранном государстве, суверенной воле не только российского народа, но и народа иностранного государства противоречит государственному суверенитету и ставит под угрозу осуществление гражданами Российской Федерации своих конституционных прав.

Наличие у гражданина вида на жительство в иностранном государстве, как правило, корреспондирует обязанности обладателя вида на жительство проживать на территории соответствующего иностранного государства. Так, согласно статье 9 Директивы 2003/109/ЕС «О статусе граждан третьих стран, проживающих на долгосрочной основе» (принята Советом Европейского

\footnotetext{
${ }^{1}$ Подпункт «а» пункта 8 статьи 29 Федерального закона «Об основных гарантиях избирательных прав и права на участие в референдуме граждан Российской Федерации».

2 Заключение ЦИК России по обращению Конституционного Суда Российской Федерации от 14 января 2010 г. в связи с рассмотрением жалобы А.М. Малицкого С.3.
} 
Союза 25 ноября 2003 года) - одного из ключевых нормативных актов в области иммиграционной политики, призванного установить единообразные условия проживания в государствах - членах Европейского Союза лиц, не являющихся их гражданами, отсутствие соответствующего лица на территории Европейского Союза в течение периода в двенадцать последовательных месяцев может служить основанием для утраты статуса долгосрочного резидента (подпункт «с» пункта 1). Данное обстоятельство может существенно осложнить работу избирательной комиссии в период проведения выборов и референдумов, поскольку избирательные комиссии являются коллегиальными органами.

Предусмотренное федеральным законом правовое ограничение для граждан Российской Федерации, имеющих вид на жительство, быть членом избирательной комиссии с правом решающего голоса, обусловлено необходимостью защиты основ конституционного строя Российской Федерации, обеспечения безопасности государства, защиты прав и свобод других лиц.

При определении порядка формирования и деятельности избирательных комиссий законодатель осуществлял такое правовое регулирование, которое, с одной стороны, отвечало бы целям обеспечения свободного волеизъявления граждан Российской Федерации при реализации ими избирательных прав, а с другой - не допускало использования публично значимых полномочий избирательных комиссий в ущерб правам и свободам граждан и иным конституционным ценностям, что относится и к определению условий назначения граждан Российской Федерации членами избирательных, комиссий с правом решающего голоса и исполнения ими соответствующих полномочий.

Вместе с тем, 22 июня 2010 г. Конституционный Суд Российской Федерации по жалобе А.М. Малицкого признал неконституционными положения подпункта «а» пункта 1 и подпункта «а» пункта 8 статьи 29 Федерального закона «Об основных гарантиях избирательных прав и права 
на участие в референдуме граждан Российской Федерации», согласно которым граждане России, имеющие вид на жительство иностранного государства, не могут быть членами территориальных избирательных комиссий с правом решающего голоса. По мнению Конституционного Суда, участие гражданина Российской Федерации, обладающего видом на жительство на территории иностранного государства, в деятельности территориальной избирательной комиссии в качестве члена с правом решающего голоса «не представляет угрозы основам конституционного строя, нравственности, здоровью, правам и законным интересам других лиц, обеспечению обороны страны и безопасности государства, не ставит под сомнение способность такого гражданина независимо, беспристрастно и с соблюдением требований закона осуществлять полномочия члена избирательной комиссии» ${ }^{1}$.

Постановление Конституционного Суда Российской Федерации по жалобе А.М. Малицкого оставляет множество вопросов.

Во-первых, распространяется ли возможность быть членами избирательных комиссий для граждан России, имеющих вид на жительство на территории иностранного государства, на иные, помимо территориальных, избирательные комиссии - участковые комиссии, комиссии муниципальных образований, окружные комиссии, комиссии субъектов Российской Федерации, Центральную избирательную комиссию Российской Федерации.

Bo-вторых, почему в одном случае наличие у гражданина вида на жительство на территории иностранного государства рассматривается как угроза основам конституционного строя, нравственности, здоровью, правам и законным интересам других лиц, обеспечению обороны страны и безопасности государства, а в другом - нет. Исходя из такой логики, можно было бы признать неконституционным ограничение пассивного

\footnotetext{
${ }^{1}$ Постановление Конституционного Суда Российской Федерации от 22 июня 2010 г. № 14-П «По делу о проверке конституционности подпункта «а» пункта 1 и подпункта «а» пункта 8 статьи 29 Федерального закона «Об основных гарантиях избирательных прав и права на участие в референдуме граждан Российской Федерации» в связи с жалобой гражданина А.М. Малицкого // Рос. газ. 2010. 7 июля.
} 
избирательного права граждан, имеющих вид на жительство на территории иностранного государства. Однако в Определении Конституционного Суда Российской Федерации от 4 декабря 2007 г. № 797-О-О «Об отказе в принятии к рассмотрению жалобы гражданина В.В. Кара-Мурзы на нарушение его конституционных прав положением пункта 3.1 статьи 4 Федерального закона «Об основных гарантиях избирательных прав и права на участие в референдуме граждан Российской Федерации» избран иной подход.

Неубедительность и противоречивость анализируемой конституционноправовой аргументации привела к тому, что в Постановлении Конституционного Суда Российской Федерации по жалобе А.М. Малицкого отсутствуют мотивировочные элементы и ссылки на Определение Конституционного Суда Российской Федерации по жалобе В.В. Кара-Мурзы

Как представляется, Конституционному Суду не следовало «стесняться» собственных решений.

Постановления Европейского Суда по правам человека от 18 ноября 2008 г. № 7/08 по делу «Тэнасе и Киртоакэ против Молдовы» (Постановление Большой Палаты Европейского Суда по правам человека от 27 апреля 2010 г. по делу «Тэнасе против Молдовы»), Постановление Конституционного Суда Российской Федерации «По делу о проверке конституционности подпункта «а» пункта 1 и подпункта «а» пункта 8 статьи 29 Федерального закона «Об основных гарантиях избирательных прав и права на участие в референдуме граждан Российской Федерации» в связи с жалобой гражданина А.М. Малицкого» и их конституционно-правовое доктринальное толкование кардинально отличаются в силу ряда причин.

Во-первых, Республика Молдова на законодательном уровне признает множественное гражданство ${ }^{1}$. Статья 62 Конституции Российской Федерации предусматривает только двойное гражданство, которое допускается лишь в

1 Закон Республики Молдова «О гражданстве Республики Молдова» от 5 июня 2003 г. № 1024 разрешил гражданам Молдовы приобретать множественное гражданство. 
соответствии с федеральным законом или международным договором Российской Федерации ${ }^{1}$. Получение гражданства другого государства иным путем не признается Российской Федерацией. Наличие у гражданина Российской Федерации гражданства иностранного государства не умаляет его прав и свобод и не освобождает от обязанностей, вытекающих из российского гражданства, если иное не предусмотрено федеральным законом или международным договором Российской Федерации. Правовые требования к кандидатам в депутаты (на выборные должности) и организаторам выборов закреплены в Федеральных законах «Об основных гарантиях избирательных прав и права на участие в референдуме граждан Российской Федерации» «О выборах Президента Российской Федерации», «О выборах депутатов Государственной Думы Федерального Собрания Российской Федерации», «О правовом положении иностранных граждан в Российской Федерации», являются необходимыми для защиты конституционно значимых ценностей, не допускают расширительного толкования и не служат оправданием ущемления прав и свобод в зависимости от национальной принадлежности или иного обстоятельства.

Во-вторых, в Российской Федерации, в отличие от Республики Молдова, отсутствуют значительные по численности группы населения, имеющие множественное гражданство ${ }^{2}$. В Постановлении Большой Палаты от 27 апреля 2010 г. Европейский Суд подчеркнул особое положение Молдавии, имевшей потенциально большую долю лиц с двойным гражданством и лишь недавно приобретшую независимость.

B-третьих, в Постановлении Европейского Суда по правам человека от 18 ноября 2008 г. № 7/08 по делу «Тэнасе и Киртоакэ против Молдовы» и

\footnotetext{
${ }^{1}$ В настоящее время действует договор между Российской Федерацией и Республикой Таджикистан об урегулировании вопросов двойного гражданства (Москва, 7 сентября 1995 г.).

2 В качестве подтверждения актуальности проблемы определения правового положения лиц, имеющих двойное гражданство в Республике Молдова, можно привести следующий пример. По данным Большой Палаты Европейского Суда по правам человека, из 3800000 молдавских граждан с 1991 по 2001 год румынское гражданство получили от 95000 до 300000 человек; в феврале 2007 г. на рассмотрении находились около 800000 ходатайств граждан Молдовы о получении румынского гражданства. Кроме того, примерно 120000 граждан Молдовы имели паспорта Российской Федерации. 21 из 101 депутатов, избранных в Парламент Молдовы 5 апреля 2009 г., имели двойное гражданство.
} 
Постановлении Большой Палаты Европейского Суда по правам человека от 27 апреля 2010 г. по делу «Тэнасе против Молдовы» в качестве аргументации используются ссылки на международные документы, ратифицированные Молдовой, но не имеющие обязательного значения для Российской Федерации ${ }^{1}$.

В Преамбуле Европейской Конвенции о гражданстве (Страсбург, 6 ноября 1997 г.), на которую ссылается Европейский Суд по правам человека, отмечаются «различные подходы государств к вопросу о множественном гражданстве» и признается, что «каждое государство вправе решать в рамках своего внутреннего законодательства, какими будут последствия того, что его гражданин приобретает или имеет другое гражданство».

Между тем, сам Европейский суд по правам человека избирательно игнорирует европейские принципы гражданства в угоду политической коньюнктуре и ограничивает суверенитет государств на выбор того или иного подхода к вопросу о множественном гражданстве и определению юридических последствий приобретения (наличия) гражданства иностранного государства. Рецепция Конституционным Судом Российской Федерации подобных решений ЕСПЧ может нанести ущерб конституционному строю, обороноспособности и безопасности государства и в связи с этим представляется преждевременной. Данные обстоятельства актуализируют проблему пределов юрисдикции ЕСПЧ в отношении органов конституционной юстиции суверенных государств и возможности пересмотра формата участия государств в международных договорах, противоречащих принципам национальной правовой системы.

Как справедливо отмечает В.П. Волков, «в новейшей истории вдохновители практически всех так называемых «цветных революций» использовали выборы как повод, а иногда как причину для отстранения от власти своих соперников. Поэтому в современных условиях государство

\footnotetext{
${ }^{1}$ Свод рекомендуемых норм при проведении выборов Венецианской комиссии Совета Европы и Европейская конвенция о гражданстве ратифицированы Молдовой в 1999 г. Данные акты не ратифицированы Российской Федерацией.
} 
вправе и обязано устанавливать такие требования или критерии для назначения членов избирательных комиссий, которые даже по формальным признакам не должны давать какого-либо повода, чтобы усомниться в наличии хоть малейшей их зависимости от влияния зарубежных заинтересованных сил. Иначе может быть поставлен вопрос о недоверии к избранной власти. ... Следует подчеркнуть, что речь идет о принципе формирования избирательных комиссий, который распространяется и на другие категории граждан России. Например, депутаты, судьи также не могут быть гражданами или иметь вид на жительство другого государства. И это ни у кого не вызывает вопросов и не порождает сомнений. Когда же речь заходит об организаторах избирательного процесса, о формировании власти, то почему-то вопросы появляются. А ведь сформированная на выборах власть участвует в формировании всех остальных ветвей власти в стране»1.

Проведенный анализ конституционно-правовой доктрины свидетельствует о наличии проблем в регулировании правового статуса лиц, обладающих иностранным гражданством или видом на жительство на территории другого государства, констатирует различие подходов европейских и российских органов конституционной юстиции к правотворчеству и правореализации при решении вопросов гражданства, актуализирует необходимость определения юридических пределов заимствования международного конституционно-правового опыта в рамках национальных правовых систем.

\footnotetext{
${ }^{1}$ Выступление члена Центральной избирательной комиссии Российской Федерации В.П. Волкова на заседании Конституционного Суда Российской Федерации по делу о проверке конституционности положений подпункта «а» пункта 1, подпункта «а» пункта 8 статьи 29 Федерального закона «Об основных гарантиях избирательных прав и права на участие в референдуме граждан Российской Федерации» в связи с жалобой гражданина А.М. Малицкого //http://www.cikrf.ru/news/relevant/2010/05/28/volkov.html
} 